\title{
Fervidobacterium gondwanense sp. nov., a New Thermophilic Anaerobic Bacterium Isolated from Nonvolcanically Heated Geothermal Waters of the Great Artesian Basin of Australia
}

\author{
K. T. ANDREWS AND B. K. C. PATEL* \\ Faculty of Science and Technology, Griffith University, Nathan, Brisbane, Queensland, Australia 4111
}

\begin{abstract}
A new thermophilic, carbohydrate-fermenting, obligately anaerobic bacterial species was isolated from a runoff channel formed from flowing bore water from the geothermally heated aquifer of the Great Artesian Basin of Australia. The cells of this organism were nonsporulating, motile, gram negative, and rod shaped and generally occurred singly or in pairs. The optimum temperature for growth was 65 to $68^{\circ} \mathrm{C}$, and no growth occurred at temperatures below $44^{\circ} \mathrm{C}$ or above $80^{\circ} \mathrm{C}$. Growth was inhibited by $10 \mu \mathrm{g}$ of lysozyme per ml, $10 \mu \mathrm{g}$ of penicillin per $\mathrm{ml}, 10 \mu \mathrm{g}$ of tetracycline per $\mathrm{ml}, 10 \mu \mathrm{g}$ of phosphomycin per $\mathrm{ml}, 10 \mu \mathrm{g}$ of vancomycin per $\mathrm{ml}$, and $\mathrm{NaCl}$ concentrations greater than $0.2 \%$. The optimum $\mathrm{pH}$ for growth was 7.0 , and no growth occurred at pH 5.5 or 8.5. The DNA base composition was $35 \mathrm{~mol} \%$ guanine plus cytosine, as determined by thermal denaturation. The end products of glucose fermentation were lactate, acetate, ethanol, $\mathrm{CO}_{2}$, and $\mathrm{H}_{2}$. Sulfur, but not thiosulfate, sulfite, or sulfate, was reduced to sulfide. Phase-contrast microscopy of whole cells and an electron microscopic examination of thin sections of cells revealed the presence of single terminal spheroids, a trait common in members of the genus Fervidobacterium. However, a phylogenetic analysis of the 16S rRNA sequence revealed that the new organism could not be assigned to either of the two previously described Fervidobacterium species. On the basis of these observations, we propose that the new organism should be designated a new Fervido-bacterium species, Fervidobacterium gondwanense. The type strain of this species is strain AB39 (= Australian Collection of Microorganisms strain ACM 5017).
\end{abstract}

The most favored ecosystems for isolating thermophilic bacteria are naturally occurring volcanic marine and terrestrial hot springs (19). However, some thermophilic bacteria have been isolated from man-made heated environments, such as hot water storage tanks (15), and from mesophilic environments, such as lake sediments (14). Waters of the large deep subsurface aquifers, which are heated geothermally because of the temperature increase of $2.13^{\circ} \mathrm{C} / 100 \mathrm{~m}$ of depth (3), are also an important potential source of phylogenetically novel thermophilic bacteria $(2,9,13)$. The Great Artesian Basin of Australia is one of the largest deep subsurface aquifers and covers approximately one-fifth of the Australian continent. Some 5,000 bore holes have been sunk into the Great Artesian Basin in order to tap this water resource, and the water is distributed on the surface by runoff channels. The water temperature at the bore source can be as high as $100^{\circ} \mathrm{C}$, and temperature gradients form in the runoff channels (5). Microbiological investigations of samples collected directly from bore source and runoff channels have revealed that there is great microbial diversity $(2,9,13)$. In this paper we describe the isolation and characterization of a new species of the genus Fervidobacterium. The results of a preliminary study of the fatty acid composition of this organism have been described previously (13).

\section{MATERIALS AND METHODS}

Bacterial cultures. Strain $\mathrm{AB} 39^{\mathrm{T}}$ ( $\mathrm{T}=$ type strain) was isolated from a runoff channel from a bore hole containing geothermal water from the Great Artesian Basin. Fenvidobacterium nodosum Rt17-B1 ${ }^{\mathrm{T}}$ (= ATCC $35602^{\mathrm{T}}$ ) was obtained from H. W. Morgan (Thermophile Research Unit, Waikato University, Hamilton, New Zealand), and Fervidobacterium islandicum $\mathrm{H}_{21}^{\mathrm{T}}$ (= DSM $5733^{\mathrm{T}}$ ) was obtained from B. Ollivier (ORSTOM Laboratoire de Microbiologie, Marseille,

* Corresponding author. Phone: 61-7-3875 7695. Fax: 61-7-3875 7800. Electronic mail address: B.Patel@sct.gu.edu.au.
France), who had obtained it from the Deutsche Sammlung von Mikroorganismen und Zellkulturen. All three strains were routinely cultured by using previously described methods $(11,12)$.

Sample source and collection. Samples were collected directly from bore sources and from runoff channels of the Great Artesian Basin of Australia. Water was collected directly in sterile containers from the bore source or a mixture of water and sediments, or microbial mats were collected from the runoff channels by scooping material into sterile glass containers. In ail cases, the containers were completely filled and capped tightly. Temperatures were determined in situ during sample collection. A total of 44 samples, whose temperatures ranged from 31 to $88^{\circ} \mathrm{C}$, were collected. The samples were transported to our laboratory at ambient temperatures and stored until they were used.

Enrichment and isolation. To initiate enrichment cultures, $0.1-$ to $0.5-\mathrm{ml}$ portions of samples were inoculated into $10-\mathrm{ml}$ portions of prereduced Trypticase-yeast extract-glucose (TYEG) medium, and the preparations were incubated at $68^{\circ} \mathrm{C}$ without agitation for up to 3 days, during which time they were examined for growth with a microscope $(11,12)$. Positive enrichment cultures were subcultured at least three times in the same medium prior to culture purification. Cultures were purified by using the end point dilution technique and TYEG medium supplemented with $2 \%$ (wt/vol) agar. A single colony from the most dilute tubes was picked, and the process of end point dilution was repeated at least twice before the culture was considered pure and used in subsequent characterization tests. The pure culture was stored in a glycerol-TYEG medium (50:50) mixture at $-20^{\circ} \mathrm{C}$.

pH, temperature, and $\mathrm{NaCl}$ concentration ranges for growth. All experiments were performed in duplicate. Growth was measured by determining the change in turbidity at $660 \mathrm{~nm}$ and also by determining the change in $\mathrm{pH}$. To measure changes in absorbance, Bellco tubes were inserted directly into a Novaspec LKB spectrophotometer (Pharmacia) which had been zeroed with uninoculated medium or water. To determine the $\mathrm{pH}$ range for growth, prereduced TYEG medium was adjusted to $\mathrm{pH}$ values between 5.0 and 10.0 by injecting appropriate volumes of sterile $\mathrm{HCl}$ or $\mathrm{NaOH}$. TYEG medium adjusted to the optimal $\mathrm{pH}$ for growth was used to determine the temperature range for growth. TYEG medium at $\mathrm{pH} 7.0$ and an incubation temperature of $65^{\circ} \mathrm{C}$ was used to determine the $\mathrm{NaCl}$ requirement.

Antibiotic susceptibility. Antibiotics were added from filter-sterilized stock solutions to sterile prereduced TYEG medium under a stream of oxygen-free nitrogen gas to give final concentrations of 10 and $100 \mu \mathrm{g} / \mathrm{ml}$.

Carbohydrate utilization and end product formation. Carbohydrate utilization was determined in prereduced TYE medium (TYEG medium lacking glucose). Soluble carbohydrates (prepared as $10 \%$ filter-sterilized stock solutions) were dispensed into tubes, and insoluble carbohydrates (final concentration, $0.5 \%$ ) were weighed directly in tubes before prereduced TYE medium was dispensed. 
Growth was measured spectrophotometrically and also by determining the change in $\mathrm{pH}$.

The fermentation end products were determined by gas-hiquid chromatography. A Shimadzu model GC8 gas chromatograph equipped with a thermal conductivity detector was used for $\mathrm{CO}_{2}$ and $\mathrm{H}_{2}$ analysis. The gases were separated on a Carbosphere $(80 / 100)$ column by using $\mathrm{N}_{2}$ at a flow rate of $8 \mathrm{ml} / \mathrm{min}$ as the carrier gas. A Shimadzu model GC14 gas chromatograph equipped with a flame ionization detector was used to analyze volatile fatty acids and lactate. The acids were separated on a Chromosorb $101(80 / 100)$ column by using $\mathrm{N}_{2}$ at a flow rate of $12.5 \mathrm{ml} / \mathrm{min}$ as the carrier gas and $\mathrm{H}_{2}$ and air at flow rates of 18 and 250 $\mathrm{ml} / \mathrm{min}$, respectively, as flame gases. The oven temperature and the injecto temperature were 180 and $200^{\circ} \mathrm{C}$, respectively. The amounts of the gases and acids were determined as described previously (12), except that the Delta computer software analysis package (Digitals Solutions, Ltd., Brisbane, Queensland, Australia) was used to integrate the peaks.

Reduction of thiosulfate, sulfite, and sulfate (final concentration, $20 \mathrm{mM}$ ) and reduction of sulfur (final concentration, $1 \%$ ) to sulfide were performed in TYEG medium $\left(\mathrm{pH} \mathrm{7.0)}\right.$ at an incubation temperature of $65^{\circ} \mathrm{C}$. Sulfide production in the culture supernatant in the early stationary phase was determined as described previously (9)

Light microscopy and electron microscopy. Light microscopy and electron microscopy were performed as described previously (12).

$\mathbf{G}+\mathbf{C}$ content. DNA was isolated and purified by using a slight modification of the method of Marmur (10) in which an RNase treatment step was included after cell lysis. DNA was resuspended in $0.1 \times$ SSC $(1 \times$ SSC is $0.15 \mathrm{M} \mathrm{NaCl}$ plus 0.015 $\mathrm{M}$ sodium citrate), and the thermal denaturation temperature was determined with a Gilford model 250 spectrophotometer equipped with a thermoprogrammer. DNA from a reference strain of Escherichia coli (ACM 1803) (Australian Collection of Microorganisms, The University of Queensland, St. Lucia, Australia) was purified by using the procedure described above, and this DNA was used as a standard when the DNA base composition was calculated.

$16 S$ rRNA sequence studies. Partially purified DNA was used for $16 \mathrm{~S}$ rRNA gene amplification as described previously $(9,17)$. The amplified $16 \mathrm{~S}$ rRNA gene products from five $50-\mu$ lubes were pooled, electrophoresed on a $0.8 \%$ agarose gel, and purified by using QIAEX (QIAGEN GmbH, Hilden, Germany) essentially as described by the manufacturer except that the final elution of DNA wa in sterile distilled water instead of Tris-EDTA buffer. The sequence was determined with an ABI automated DNA sequencer by using a Prism dideoxy terminator cycle sequencing kit and the protocols recommended by the manufacture (Applied Biosystems, Inc.). The primers used for sequencing have been described previously (17). The $16 \mathrm{~S}$ rRNA gene sequence which we determined was manually aligned with reference sequences of various members of the domain Bacteria by using editor ae2. Reference sequences were obtained from the $\mathrm{Ri}$ bosomal Database Project (8) and GenBank databases. Positions of sequence and alignment uncertainty were omitted from the analysis. A phylogenetic analysis was performed by using various programs implemented as part of the PHYLIP package (4), as described below. The pairwise evolutionary distance based on 1,100 unambiguous nucleotides were determined by using the metho of Jukes and Cantor (7), and dendrograms were constructed from evolutionary distances by using the neighbor-joining method. A transversion analysis was performed by using the program DNAPARS. Tree topology (determined by using 1,000 bootstrapped data sets) was reexamined by running a script consisting of the following programs: SEQBOOT, DNADIST, NEIGHBOR, and CONSENSE. A program available on TREECON (20) was also used for phylogenetic analysis.

Nucleotide sequence accession number. The nucleotide sequence of the $16 \mathrm{~S}$ rRNA gene of strain $\mathrm{AB} 39^{\mathrm{T}}$ has been deposited in the EMBL database under accession number Z49117.

\section{RESULTS}

Enrichment and isolation. Of the 44 samples examined, 21 gave rise to positive enrichment cultures after $48 \mathrm{~h}$ of incubation at $68^{\circ} \mathrm{C}$. Eight of these enrichment cultures contained organisms that had conventional rod and filament morphologies, whereas the remaining 13 contained rods that had single terminal swellings. The organisms that exhibited the latter morphotype were isolated from bore source samples, as well as from sediment and microbial mat samples. The temperatures of the sites from which these samples were obtained ranged from 31 to $75^{\circ} \mathrm{C}$. Organisms that exhibited this morphotype were not found in enrichment cultures prepared with samples that had been collected from sites where the temperatures were 76 to $88^{\circ} \mathrm{C}$. Pure isolates were obtained from enrichment cultures by using the end point dilution technique and were stored at $-20^{\circ} \mathrm{C}$. A pure culture that was obtained from en- richment cultures initiated from a $66^{\circ} \mathrm{C}$ microbial mat sample and designated strain $\mathrm{AB} 39^{\mathrm{T}}$ was studied further.

Growth of strain $A B 39^{\mathrm{T}}$ was inhibited in TYEG medium culture tubes when the $\mathrm{N}_{2}$ gas phase was replaced with air or in TYEG medium which lacked a reductant, indicating that strain $\mathrm{AB} 39^{\mathrm{T}}$ was an obligate anaerobe.

Morphology and cell structure. Strain $\mathrm{AB} 39^{\mathrm{T}}$ cells were rods and occurred singly, in pairs, or in short chains. They were motile, gram negative, 0.5 to $0.6 \mu \mathrm{m}$ in diameter, and 4 to 40 $\mu \mathrm{m}$ long. Protuberances or swellings were usually present at the ends of the bacteria and were observed at all growth temperatures. Only one swelling was present in each cell. The swellings ranged from 1 to $4 \mu \mathrm{m}$ in diameter (Fig. 1a). Occasionally, giant spheres consisting of membrane-bound structures containing two or more cells and ranging in diameter from 5 to $8 \mu \mathrm{m}$ were also observed. Phase-contrast microscopy of cultures grown at different temperatures and $\mathrm{pH}$ values did not reveal any spores.

Electron microscopy of thin sections of strain $\mathrm{AB} 39^{\mathrm{T}}$ revealed a typical gram-negative two-layer cell wall structure (Fig. 1c). The outer layer protruded to form the characteristic swollen structure, whereas the inner layer remained tightly associated with the cell membrane (Fig. 1b and c).

Optimal growth conditions. $\mathrm{NaCl}$ was not required for growth, and concentrations of $\mathrm{NaCl}$ greater than $0.2 \%$ were inhibitory. Strain $\mathrm{AB} 39^{\mathrm{T}}$ grew optimally at 65 to $68^{\circ} \mathrm{C}$, and no growth occurred at temperatures of $44^{\circ} \mathrm{C}$ or below or above $80^{\circ} \mathrm{C}$. The optimum $\mathrm{pH}$ for growth was 7.0 , and no growth occurred at $\mathrm{pH} 5.5$ or 8.5. The generation time of strain $\mathrm{AB} 39^{\mathrm{T}}$ in TYEG medium at $\mathrm{pH} 7.0$ and $65^{\circ} \mathrm{C}$ was $79 \mathrm{~min}$.

Substrate utilization, sulfide production, and fermentation end products. The substrates that supported growth of strain $\mathrm{AB} 39^{\mathrm{T}}$ included D-cellobiose, amylopectin, maltose, starch, dextrin, xylose, glucose, pyruvate, lactose, fructose, and mannose (Table 1). Carboxymethyl cellulose and galactose were fermented slowly, whereas Casamino Acids, gelatin, L-sorbose, chitin, dextran, arabinose, ribose, raffinose, and cellulose did not support growth.

The end products formed during glucose fermentation included ethanol $(2 \mathrm{mM})$, acetate $(7 \mathrm{mM})$, lactate $(15 \mathrm{mM})$, $\mathrm{CO}_{2}$, and $\mathrm{H}_{2}$.

Sulfur, but not thiosulfate, sulfite, or sulfate, was reduced to sulfide.

Antibiotic susceptibility. Growth of strain $\mathrm{AB} 39^{\mathrm{T}}$ was completely inhibited by $10 \mu \mathrm{g}$ of streptomycin per $\mathrm{ml}, 10 \mu \mathrm{g}$ of penicillin per $\mathrm{ml}, 10 \mu \mathrm{g}$ of novobiocin per $\mathrm{ml}, 10 \mu \mathrm{g}$ of phosphomycin per $\mathrm{ml}, 10 \mu \mathrm{g}$ of tetracycline per $\mathrm{ml}, 10 \mu \mathrm{g}$ of vancomycin per $\mathrm{ml}, 100 \mu \mathrm{g}$ of polymyxin B per $\mathrm{ml}, 100 \mu \mathrm{g}$ of chloramphenicol per $\mathrm{ml}$, or $100 \mu \mathrm{g}$ of rifampin per mi.

DNA base composition. The DNA base composition of strain $\mathrm{AB} 39^{\mathrm{T}}$ was $35 \mathrm{~mol} \% \mathrm{G}+\mathrm{C}$. The $E$. coli reference DNA used had a melting temperature of $76.6^{\circ} \mathrm{C}$, corresponding to a $\mathrm{G}+\mathrm{C}$ content of $51.2 \mathrm{~mol} \%$.

16S rRNA sequence analysis. Using eight primers, we determined the sequence of 1,478 bases from position 27 to position 1540 (E. coli numbering of Winker and Woese [21]) of the $16 \mathrm{~S}$ rRNA gene of strain $\mathrm{AB} 39^{\mathrm{T}}$. The $\mathrm{G}+\mathrm{C}$ content of this 16S rRNA gene was $59.63 \mathrm{~mol} \%$. A phylogenetic analysis performed with representatives of the domain Bacteria revealed that strain $\mathrm{AB} 39^{\mathrm{T}}$ is a member of the order Thermotogales, and an analysis performed with members of the order Thermotogales indicated that strain $\mathrm{AB} 39^{\mathrm{T}}$ is closely related to the type strains of the two previously described Fervidobacterium species, $F$. nodosum Rt17-B1 and $F$. islandicum $\mathrm{H} 21$ (levels of similarity, 94 and $95 \%$, respectively. Figure 2 is a dendrogram that was generated by the neighbor-joining method from the 

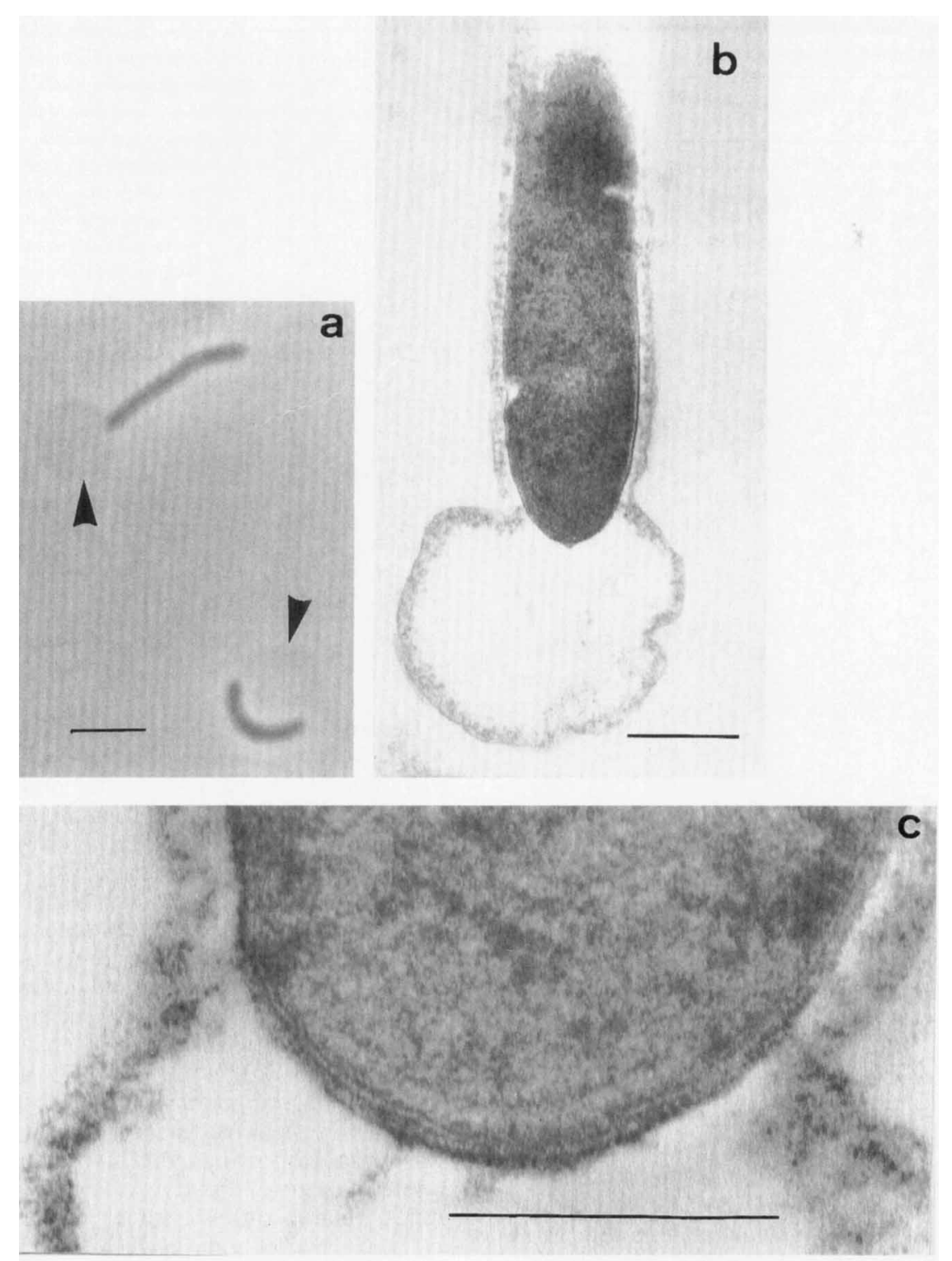

FIG. 1. (a) Phase-contrast micrograph of strain $\mathrm{AB} 39^{\mathrm{T}}$ showing the presence of spheroid structures (arrowheads). Bar $=2 \mu \mathrm{m} .(\mathrm{b}$ and $\mathrm{c})$ Electron micrographs of a thin section of a whole cell showing the spheroid structure as part of the outer cell wall (b) and the inner cell wall associated with the cell membrane (c). Bars $=0.2$ $\mu \mathrm{m}$.

evolutionary distance matrix and shows this relationship. A bootstrap analysis of the data revealed a modest relationship between strain $\mathrm{AB} 39^{\mathrm{T}}$ and $F$. islandicum $\mathrm{H} 21^{\mathrm{T}}(73 \%)$, although the confidence level obtained for $F$. nodosum and the other two Fervidobacterium species was $100 \%$.

\section{DISCUSSION}

Numerous genera and species of gram-negative, thermophilic, motile, anaerobic, carbohydrate-fermenting, rod-shaped bacteria have been described. However, as strain $\mathrm{AB} 39^{\mathrm{T}}$ produces terminal protuberances or swellings, its morphology is clearly similar to the morphology of members of the order Thermotogales. In a previous study Patel et al. found high levels of saturated, normal fatty acids ( $78 \%$ of the total fatty acids) and that fatty acids with even numbers of carbon atoms predominated; these findings also indicated that strain $\mathrm{AB} 39^{\mathrm{T}}$ is a member of the order Thermotogales (13). In addition, the pro- tuberances of strain $\mathrm{AB} 39^{\mathrm{T}}$ cells closely resemble the spheroids of Fervidobacterium strains (12) rather than the sheathlike structures called "togas" that are characteristic of Thermotoga, Petrotoga, and Geotoga species $(1,16,19)$. Further evidence of the relationship of strain $\mathrm{AB} 39^{\mathrm{T}}$ to $F$. nodosum $\mathrm{Rt} 17-\mathrm{B} 1^{\mathrm{T}}$ and $F$. islandicum $\mathrm{H} 21^{\mathrm{T}}$ was also obtained from a phylogenetic analysis of the 16S rRNA gene.

Fervidobacterium species, including $F$. nodosum and $F$. islandicum, have been isolated previously only from volcanic hot springs $(6,12)$. This paper is the first report of the isolation of a Fervidobacterium strain from a nonvolcanic, geothermally heated water source (viz., the Great Artesian Basin of Australia). The presence of Fervidobacterium isolates in the aquifer was not rare, as morphologically similar strains were isolated from another 12 of the 44 enrichment samples examined. As Fervidobacterium strains were isolated from water samples collected from bore holes that were up to $1,500 \mathrm{~m}$ deep, we 
TABLE 1. Differential characteristics of members of the genus Fervidobacterium ${ }^{a}$

\begin{tabular}{|c|c|c|c|}
\hline Characteristic & $\begin{array}{l}\text { F. gondwanense } \\
\qquad \mathrm{AB} 39^{\mathrm{T} b}\end{array}$ & $\begin{array}{l}\text { F. nodosum } \\
\text { Rt17-B1 }{ }^{\mathrm{Tc}}\end{array}$ & $\begin{array}{l}\text { F. islandicum } \\
\mathrm{H} 21^{\mathrm{T} d}\end{array}$ \\
\hline Habitat & $\begin{array}{l}\text { Geothermal arte- } \\
\text { sian waters of } \\
\text { Australia }\end{array}$ & $\begin{array}{l}\text { Volcanic hot } \\
\text { springs of } \\
\text { New Zealand }\end{array}$ & $\begin{array}{l}\text { Volcanic hot } \\
\text { springs of } \\
\text { Iceland }\end{array}$ \\
\hline Cell diam $(\mu \mathrm{m})$ & $0.5-0.6$ & $0.5-0.55$ & 0.6 \\
\hline Cell length $(\mu \mathrm{m})$ & $4-40$ & $1-2.5$ & $1-4$ \\
\hline Temp range $\left({ }^{\circ} \mathrm{C}\right)$ & $>45-<80$ & $47-80$ & $50-80$ \\
\hline Optimum temp $\left({ }^{\circ} \mathrm{C}\right)$ & $65-68$ & 70 & 65 \\
\hline $\mathrm{pH}$ range & $6.0-8.0$ & $6.0-8.0$ & $6.0-8.0$ \\
\hline Optimum $\mathrm{pH}$ & 7.0 & 7.0 & 7.2 \\
\hline $\mathrm{NaCl}$ concn range $(\%)$ & $0-0.6$ & $<1$ & $<1$ \\
\hline $\begin{array}{l}\text { Optimum } \mathrm{NaCl} \\
\text { concn }(\%)\end{array}$ & 0.1 & $\mathrm{NR}^{e}$ & 0.2 \\
\hline Generation time (min) & 79 & 105 & 150 \\
\hline $\mathrm{G}+\mathrm{C}$ content $(\mathrm{mol} \%)$ & 35 & 33.7 & 41 \\
\hline \multicolumn{4}{|l|}{$\begin{array}{l}\text { Utilization of the fol- } \\
\text { lowing substrates: }\end{array}$} \\
\hline $\begin{array}{l}\text { Carboxymethyl cellu- } \\
\text { lose }\end{array}$ & + & - & - \\
\hline Lactose & + & + & - \\
\hline Starch & + & + & - \\
\hline Dextrin & + & + & - \\
\hline Fructose & + & - & - \\
\hline Xylose & + & - & - \\
\hline Arabinose & - & - & + \\
\hline Pyruvate & + & - & + \\
\hline Galactose & + & + & - \\
\hline
\end{tabular}

${ }^{a}$ All three species are spheroid-structure-bearing bacteria.

${ }^{b}$ Data from this study.

c Data from reference 12

${ }^{d}$ Data from reference 6 .

"NR, not reported.

${ }^{f}$ Data from this study. All three Fervidobacterium species utilized glucose, mannose, maltose, amylopectin, and cellobiose but not cellulose, Casamino Acids, gelatin, sorbose, xylan, dextran, or chitin. +, growth; -, no growth.

speculate that the primary habitat of these bacteria is the geothermal waters of the deep aquifer and that they are seeded into the runoff channels, where they adapt to the new environment. The water of the Great Artesian Basin aquifer is meteoric in origin, and the rate of water flow underground is approximately $5 \mathrm{~m} /$ year (5); therefore, this water could provide a conducive environment for microbial growth. The modest confidence value $(73 \%)$ between $F$. nodosum or $F$. islandicum and strain $\mathrm{AB} 39^{\mathrm{T}}$ indicates that there may be Fervidobacterium species that remain to be identified. Some Fervidobacterium isolates obtained from the Great Artesian Basin that are currently being investigated in our laboratory differ markedly in their ability to reduce thiosulfate or sulfur. Sequencing of the $16 \mathrm{~S}$ rRNA genes of these isolates for phylogenetic identification is currently in progress.

Strain $\mathrm{AB} 39^{\mathrm{T}}$ can be differentiated from $F$. nodosum Rt17$\mathrm{B} 1^{\mathrm{T}}$ and $F$. islandicum $\mathrm{H} 21^{\mathrm{T}}$ on the basis of its fast growth rate and its greater nutritional versatility. Strain $\mathrm{AB} 39^{\mathrm{T}}$ also has a lower $\mathrm{G}+\mathrm{C}$ content $(35 \mathrm{~mol} \%)$ than $F$. islandicum $\mathrm{H} 21^{\mathrm{T}}$ (41 mol\%) (Table 1). Phylogenetically, strain $A B 39^{\mathrm{T}}$ is more closely related to $F$. islandicum $\mathrm{H} 21^{\mathrm{T}}$ (level of similarity, 95\%) than to $F$. nodosum $\mathrm{Rt} 17-\mathrm{B} 1^{\mathrm{T}}$ (level of similarity, 94\%). Recently, Stackebrandt and Goebel (18) concluded that strains belonging to the same genus that exhibit less than $97 \% 16 \mathrm{~S}$ rRNA sequence similarity should be considered members of different species. Thus, it is clear that strain $\mathrm{AB} 39^{\mathrm{T}}$ is a member of a new Fervidobacterium species, for which we propose the name Fervidobacterium gondwanense.

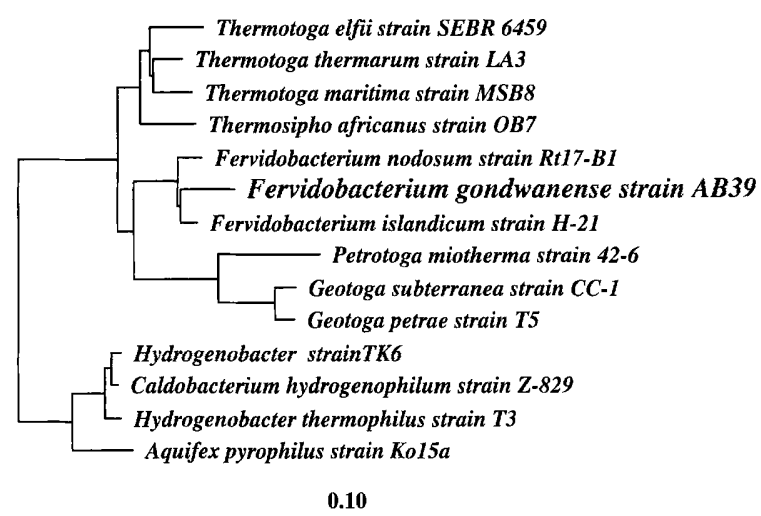

FIG. 2. Dendrogram showing the positions of strain $\mathrm{AB} 39^{\mathrm{T}}$, members of the order Thermotogales, and related bacteria. The dendrogram was constructed by using the neighbor-joining method and Jukes-Cantor evolutionary distance matrix data obtained from a comparison of 1,100 unambiguous nucleotides as implemented in PHYLIP (4). The sequences used in the analysis were obtained from the Ribosomal Database Project, version 4.1 (10), and from the GenBank database. The GenBank accession numbers for the Hydrogenobacter thermophilus, Caldobacterium hydrogenophilum, and Hydrogenobacter sp. strain T3 sequences are Z30214, Z30242, and Z30189, respectively. Bar = evolutionary distance.

Description of Fervidobacterium gondwanense sp. nov. Fervidobacterium gondwanense (Gond.wa.nen'se. M.L. neut. adj. gondwanense, pertaining to the large land mass known as Gondwana, which included Australia, Africa, India, and South America before they separated). Straight motile rods that are 0.5 to 0.6 by 4 to $40 \mu \mathrm{m}$ and occur singly, in pairs, or in chains. Gram negative. Cells produce terminal spheroid structures which are protuberances of the outer cell wall. Rotund bodies are formed rarely. No spores are produced. Creamish brown colonies that are $1 \mathrm{~mm}$ in diameter develop in TYEG medium containing $2.5 \%$ agar after $48 \mathrm{~h}$ of incubation at $65^{\circ} \mathrm{C}$.

Chemoorganotrophic, strictly anaerobic bacterium which grows at temperatures of $>45^{\circ} \mathrm{C}$ or $<80^{\circ} \mathrm{C}$ and at $\mathrm{pH} 6.0$ to 8.0 . The optimum temperature is 65 to $68^{\circ} \mathrm{C}$, and the optimum $\mathrm{pH}$ is 7.0. Utilizes glucose, mannose, maltose, starch, amylopectin, cellobiose, carboxymethyl cellulose, lactose, dextrin, fructose, xylose, galactose, and pyruvate but not cellulose, Casamino Acids, gelatin, sorbose, ribose, raffinose, arabinose, dextran, xylan, or chitin. Produces acetate, ethanol, lactate, $\mathrm{CO}_{2}$, and $\mathrm{H}_{2}$ during glucose fermentation. Reduces sulfur but not thiosulfate, sulfite, or sulfate. A member of the domain Bacteria. Growth is inhibited by streptomycin, penicillin G, polymyxin B, phosphomycin, tetracycline, vancomycin, chloramphenicol, and rifampin, partially inhibited by sodium azide and neomycin, and not inhibited by D-cycloserine.

The $\mathrm{G}+\mathrm{C}$ content of the DNA is $35 \mathrm{~mol} \%$, as determined by thermal denaturation.

Phylogenetically related to members of the order Thermotogales, particularly $F$. nodosum $\mathrm{Rt} 17-\mathrm{B} 1^{\mathrm{T}}$ and $F$. islandicum $\mathrm{H} 21^{\mathrm{T}}$.

Isolated from nonvolcanic geothermal waters of the Great Artesian Basin, an aquifer in Australia.

The type strain is strain AB39 (= Australian Collection of Microorganisms strain ACM 5017).

\section{ACKNOWLEDGMENTS}

This work was supported in part by the Australian Research Council. We thank the Water Resources Commission staff for help with sample collection. We also thank L. Sly for the use of the Gilford spectrophotometer and for providing the E. coli type strain and D. Stenzel for assistance with electron microscopy. 


\section{REFERENCES}

1. Davey, M. E., W. A. Wood, R. Key, K. Nakamura, and D. A. Stahl. 1993. Isolation of three species of Geotoga and Petrotoga: two new genera representing a new lineage in the bacterial line of descent distantly related to the "Thermotogales." Syst. Appl. Microbiol. 16:191-200.

2. Denman, S., K. Hampson, and B. K. C. Patel. 1991. Isolation of strains of Thermus aquaticus from the Australian Artesian Basin and a simple and rapid procedure for the preparation of their plasmids. FEMS Microbiol. Lett. 82:73-78.

3. Driscoll, F. G. 1986. Groundwater and wells, 2nd ed. Johnson Division, St. Paul, Minn.

4. Felsenstein, J. 1993. PHYLIP (phylogenetic inference package), version 3.51c. Department of Genetics, University of Washington, Seattle.

5. Habermehl, M. A. 1980 . The Great Artesian Basin, Australia. BMR (Bur. Miner. Resour.) J. Aust. Geol. Geophys. 5:9-38.

6. Huber, R., C. R. Woese, T. A. Langworthy, J. K. Kristjansson, and K. O. Stetter. 1990. Fervidobacterium islandicum sp. nov., a new extremely thermophilic eubacterium belonging to the "Thermotogales." Arch. Microbiol. 154:105-111.

7. Jukes, T. H., and C. R. Cantor. 1969. Evolution of protein molecules, p. 21-132. In H. N. Munro (ed.), Mammalian protein metabolism. Academic Press, New York.

8. Larsen, N., G. J. Olsen, B. L. Maidak, M. J. McCaughey, R. Overbeek, T. J. Macke, T. L. Marsh, and C. R. Woese. 1993. The Ribosomal Database Project. Nucleic Acids Res. 21:3021-3023.

9. Love, C. A., B. K. C. Patel, P. D. Nichols, and E. Stackebrandt. 1993. Desulfotomaculum australicum, sp. nov., a thermophilic sulfate-reducing bacterium isolated from the Great Artesian Basin of Australia. Syst. Appl. Microbiol. 16:244-251.

10. Marmur, J. 1961. A procedure for the isolation of deoxyribonucleic acid from bacteria. J. Mol. Biol. 3:208-218.

11. Patel, B. K. C., H. W. Morgan, and R. M. Daniel. 1985. A simple and efficient method for preparing and dispensing anaerobic media. Biotechnol. Lett. 7: 277-288.

12. Patel, B. K. C., H. W. Morgan, and R. M. Daniel. 1985. Fervidobaeterium nodosum gen. nov. and spec. nov., a new chemoorganotrophic, caldoactive. anaerobic bacterium. Arch. Microbiol. 141:63-69.

13. Patel, B. K. C., J. H. Skerratt, and P. D. Nichols. 1991. The phospho ester-linked fatty acid composition of thermophilic bacteria. Syst. Appi Microbiol. 14:311-316.

14. Phllips, W. E., and J. J. Perry. 1976. Thermomicrobium fosteri sp. now., a hydrocarbon-utilizing obligate thermophile. Int. J. Syst. Bacteriol. 26:220225.

15. Ramaley, R. F., and K. Bitzinger. 1975. Types and distribution of obligate thermophilic bacteria in man-made and natural gradients. Appl. Microbiol. 30: $152-155$.

16. Ravot, G., M. Magot, M. L. Fardeau, B. K. C. Patel, G. Prensier, A. Egan, J. L. Garcia, and B. Ollivier. 1995. Thermotoga elfi sp. nov., a novel thermor philic bacterium from an African oil-producing well. Int. J. Syst. Bacteriol. 45:308-314.

17. Redburn, A. C., and B. K. C. Patel. 1993. Phylogenetic analysis of Desulfotomaculum thermobenzoicum using polymerase chain reaction-amplified $16 \mathrm{~S}$ rRNA-specific DNA. FEMS Microbiol. Lett. 113:81-86.

18. Stackebrandt, E., and B. M. Goebel. 1994. Taxonomic note: a place for DNA-DNA reassociation and $16 \mathrm{~S}$ rRNA sequence analysis in the present species definition in bacteriology. Int. J. Syst. Bacteriol. 44:846-849.

19. Stetter, K. O., G. Fiala, G. Huber, R. Huber, and A. Segerer. 1990. Hyperthermophilic microorganisms. FEMS Microbiol. Rev. 75:117-124.

20. Van de Peer, Y., and R. De Wachter. 1992. TREECON: a software package for the construction and drawing of evolutionary trees. Comput. Appl. Biosci. 9:177-182.

21. Winker, S., and C. R. Woese. 1991. A definition of the domains Archaea, Bacteria and Eucarya in terms of small subunit ribosomal RNA characteristics. Syst. Appl. Microbiol. 14:305-310. 